\title{
The Development of Malaysian Body Somatotype Model using Comprehensive Multivariate Techniques
}

\author{
Amilah Fadhlina Mohd Rozi, Mohamad Razali Abdullah, Siti Musliha Mat Rasid, Ahmad Bisyri \\ Husin Musawi Maliki, Muhammad Rabani Hashim, Amr Salem Falah Alnamat, Mat Noor Bidin
}

\begin{abstract}
This study was designed to develop Malaysian body somatotype model among U21 athletes using multivariate analysis. A total of 85 athletes (aged $20.5 \pm 5.5$ year) were participated in the assessment of anthropometrics measurements. They were from three types of sports which are weightlifter, futsal and Sepak Takraw. These selected sports were represented three categories of body somatotypes namely endomorph, mesomorph and ectomorph respectively. Discriminant Analysis (DA) was used to determine the model and validate the accuracy of these groups classification. As the result, DA obtained $98.8 \%$ variability with two factors. First factor $(F 1)$ revealed $85.9 \%$ discrimination while second factor (F2) revealed $12.9 \%$ discrimination as it is related to anthropometrics and the variation of three groups significantly. A body somatotype model was generated using the standardized coefficient of F1. Standard DA showed three discriminated variables (height, sitting height and weight) with $67.06 \%$ percentage of correctness. While forward and backward stepwise mode assigned two discriminated variables (weight and height) with $69.41 \%$ percentage of correctness. They were established as essential indicators for differentiating body physical category.
\end{abstract}

Index Terms: Anthropometrics, Multivariate Analysis, Somatotype, Youth

\section{INTRODUCTION}

Body shape and composition play an important role in sports with a major physical component. There are evidence that shows somatotype, which is a quantified description describing a person's body shape and sport performances are related [1]. In facts, anthropometry helps to indicate or predict whether a player would be appropriate to participate in a specific sport at the best level [2] and it is obvious where the structural appearance or a person's body shape is

Revised Manuscript Received on April 25, 2019.

Amilah Fadhlina Mohd Rozi, Faculty of Applied Social Science, Universiti Sultan Zainal Abidin, Terengganu Malaysia.

Mohamad Razali Abdullah, Faculty of Applied Social Science, Universiti Sultan Zainal Abidin, Terengganu Malaysia.

Hafizan Juahir, East Coast Enviromental Research Institute, Universiti Sultan Zainal Abidin, Terengganu, Malaysia.

Siti Musliha Mat-Rasid, Faculty of Applied Social Science, Universiti Sultan Zainal Abidin, Terengganu, Malaysia.

Ahmad Bisyri Husin Musawi Maliki, Faculty of Applied Social Science, Universiti Sultan Zainal Abidin, Terengganu, Malaysia.

Muhammad Rabani Hashim, Faculty of Applied Social Science, Universiti Sultan Zainal Abidin, Terengganu, Malaysia.

Amr Alnaimat, Faculty of Applied Social Science, Universiti Sultan Zaina Abidin, Terengganu, Malaysia.

Mat Noor Bidin, Terengganu State Sports Council, Terengganu, Malaysia determined by her or his genotype which is influenced by their environment usually [3]. The quantified morphological characteristic of the athletes can be an aspect of relating body shapes to sports performance [4]. In the world of research, somatotype is well known as a description of a person's body condition which is presented numerically; three-numbered rating called endomorph, mesomorph and ectomorph [5]. It helps providing an accurate description of human physiques. Somatotyping impacted hugely in affecting to linear anthropometric measures to differentiate various competitive sports. Besides a range of differences of anthropometric and physiologic variables as results of player's position in any sort of sports [6].

Considering the importance of identifying the physical characteristics of body, this study aims to develop Malaysian body somatotype model among U21 athletes using comprehensive multivariate analysis.

\section{MATERIALS AND METHODS}

\section{A. Participant}

The anthropometric measurement data in this study were obtained from Malaysia Game (SUKMA) athletes in Terengganu, Malaysia aged under 21 (U21). Among them, there 48 male and 37 female athletes.

\section{B. Anthropometric Measurements}

Anthropometric measurement involved in this study were included weight, standing height, sitting height and armspan. The weight is measured by using a weighing scale that is placed on a flat stable position before measuring in kilogram ( $\mathrm{kg}$ ). Reading shown on the scale were recorded. The height is measured by using a stadiometer which is placed on a flat stable surface and leaned against a flat wall surface. The measurement of the distance on the stadiometer were recorded once the respondent has stepped onto it. The measurement of sitting height is measured by measuring the distance of the highest point of the head to the base sitting area in centimeter $(\mathrm{cm})$ by using a stadiometer. Simply record the reading that is indicated by the instrument. For arm span, it is measured by a measuring tape. The distance of the middle finger tip of the left arm is measured until the middle finger of the left hand in centimeter. 
in step by step starting from the most important variable until no significant changes is presented.

\section{RESULT}

\section{Data Analysis}

A matrix set of athlete group contain 340 matrices data (4 variables $\times 85$ athletes) were computed in this research. For the data analysis screening, a method was applied using XLSTAT 2014 add-in software [7,8]. This method examines the distance between each point and the closest point to it. The nearest neighbor method is the simplest method to be applied, where the end points of the gaps are used as estimation of all missing values $[9,10]$.

Discriminate Analysis (DA): DA was utilized in this research to specify the groups whether they are vary with respect to the mean of a variable and to utilize that variable to expect group membership [11]. There are three sampling groups assigned to be classified (endomorph, mesomorph and ectomorph) proposed by newly developed somatotype model. The DA was put into the raw data using the standard, forward stepwise, and backward stepwise methods [12]. To evaluate the relative somatotype variations in the anthropometric measurements, the DFs were constructed through DA. The somatotype categories of the athletes regarding to their sports involved were treated as the dependent variables while the rest of the components evaluated are independent variables. In backward stepwise mode, the variables are omitted step by step from the least important variable until zero significant change is presented. While in forward stepwise mode, the variables are calculated

Table 1: Descriptive statistics of variables among U21 athletes

\begin{tabular}{|c|c|c|c|c|c|}
\hline Variables & Sports & Min & Max & $\begin{array}{c}\text { Mea } \\
n\end{array}$ & SD \\
\hline \multirow{3}{*}{$\begin{array}{l}\text { Weight } \\
(\mathrm{kg})\end{array}$} & $\begin{array}{c}\text { Weightlifte } \\
\text { r }\end{array}$ & 49.4 & $\begin{array}{c}106 . \\
7\end{array}$ & 72.6 & $\begin{array}{c}14 . \\
9\end{array}$ \\
\hline & Futsal & 43.6 & 74.4 & 56.0 & $\begin{array}{c}8.1 \\
7 \\
\end{array}$ \\
\hline & $\begin{array}{c}\text { Sepak } \\
\text { Takraw }\end{array}$ & 41.0 & 76.7 & 59.5 & $\begin{array}{c}9.2 \\
3 \\
\end{array}$ \\
\hline \multirow{3}{*}{$\begin{array}{l}\text { Height } \\
(\mathrm{cm})\end{array}$} & $\begin{array}{c}\text { Weightlifte } \\
\text { r }\end{array}$ & $\begin{array}{c}149 . \\
0\end{array}$ & $\begin{array}{c}177 . \\
0\end{array}$ & 162.4 & 7.5 \\
\hline & Futsal & $\begin{array}{c}148 . \\
0\end{array}$ & 18.0 & 161.0 & 7.8 \\
\hline & $\begin{array}{c}\text { Sepak } \\
\text { Takraw }\end{array}$ & $\begin{array}{c}153 . \\
3 \\
\end{array}$ & $\begin{array}{c}186 . \\
9 \\
\end{array}$ & 168.3 & $\begin{array}{c}10 . \\
4 \\
\end{array}$ \\
\hline \multirow{3}{*}{$\begin{array}{l}\text { Sitting } \\
\text { Height } \\
(\mathrm{cm})\end{array}$} & $\begin{array}{c}\text { Weightlifte } \\
\text { r }\end{array}$ & 76 & 91.8 & 83.6 & 4.2 \\
\hline & Futsal & 43.5 & 91.5 & 80.1 & 7.5 \\
\hline & $\begin{array}{c}\text { Sepak } \\
\text { Takraw }\end{array}$ & 77.2 & 93.2 & 84.8 & 4.6 \\
\hline \multirow{3}{*}{$\begin{array}{l}\text { Arm } \\
\text { Span } \\
(\mathrm{cm})\end{array}$} & $\begin{array}{c}\text { Weightlifte } \\
\text { r }\end{array}$ & 150 & 186 & 168.2 & 9.5 \\
\hline & Futsal & 148 & 184 & 162.9 & 9.4 \\
\hline & $\begin{array}{c}\text { Sepak } \\
\text { Takraw }\end{array}$ & 147 & $\begin{array}{c}187 . \\
8 \\
\end{array}$ & 168.8 & $\begin{array}{c}12 . \\
9 \\
\end{array}$ \\
\hline
\end{tabular}

Table 1 presents the descriptive statistic of anthropometric measurements according to types of sports. From the table, weightlifter recorded the highest mean of weight $(72.6 \mathrm{~kg})$ with middle mean of height $(162.4 \mathrm{~cm})$, sitting height $(83.6$ $\mathrm{cm})$ and armspan $(168.2 \mathrm{~cm})$. Futsal recorded the lowest mean of weight $(56.0 \mathrm{~kg})$, height $(161.0 \mathrm{~cm})$, sitting height $(80.1 \mathrm{~cm})$ and armspan $(162.9 \mathrm{~cm})$. Meanwhile, Sepak Takraw recorded the middle mean of weight $(59.5 \mathrm{~kg})$ with the highest mean of height $(168.3 \mathrm{~cm})$, sitting height $(84.8$ $\mathrm{cm})$ and armspan $(168.8 \mathrm{~cm})$. These statistics summary for each sports lead this study for representing each category of body somatotype of endomorph, mesomorph and ectomorph with weightlifter, futsal and Sepak Takraw respectively.

Table 2 shows two factors loading and first factor (F1) consist of eigenvalues greater than 1 . The first factor reacted heavily on weight $(-0.700)$, height $(0.217)$, sitting height $(-0.062)$ and arm span (-0.094) while the second factor (F2) shows that weight $(0.635)$, height $(0.795)$, sitting height (0.861) and arm span (0.649). This is the correlation between the original variables and the factors. The higher the value of factor loads, the higher their contribution in the model [13]. The contribution of each variable to the factor scores are shown in the factor score coefficient matrix. The factor score coefficient matrix shows the coefficients or weights by which variables were multiplied to attain factor scores [14,15]. It shows that Factor 1 has a greater eigenvalue as well as a higher discrimination percentage which is $85.9 \%$.

Table 2: Variables and discriminated loading

\begin{tabular}{|l|c|c|c|c|}
\hline \multirow{2}{*}{ Variables } & \multicolumn{2}{|c|}{$\begin{array}{c}\text { Discriminated } \\
\text { loading }\end{array}$} & \multicolumn{2}{c|}{$\begin{array}{c}\text { Standardized } \\
\text { coefficient }\end{array}$} \\
\cline { 2 - 5 } & $\mathrm{F} 1$ & $\mathrm{~F} 2$ & $\mathrm{~F} 1$ & $\mathrm{~F} 2$ \\
\hline Weight $(\mathrm{kg})$ & -0.7 & 0.635 & -0.901 & 0.391 \\
\hline Height $(\mathrm{cm})$ & 0.217 & 0.795 & 2.216 & 1.162 \\
\hline $\begin{array}{l}\text { Sitting Height } \\
(\mathrm{cm})\end{array}$ & -0.062 & 0.861 & -0.189 & 0.479 \\
\hline Armspan (cm) & -0.094 & 0.649 & -1.506 & -0.947 \\
\hline Eigenvalue & 1.044 & 0.171 & & \\
\hline $\begin{array}{l}\text { Discrimination } \\
(\%)\end{array}$ & 85.9 & 12.9 & & \\
\hline Cumulative \% & 85.9 & 98.8 & \multicolumn{2}{|c}{} \\
\hline
\end{tabular}

Table 3 shows the discriminant analysis results for the further analysis. Network applied by DA is to examine variation of somatotype groups. The groups act as the dependent variable, whereas anthropometric parameters were treated as independent variables. Standard stepwise, forward stepwise and backward stepwise mode are selected to run DA. Classification accuracy using standard, backward stepwise and forward stepwise mode were $67.06 \%$ (three independent variables), $69.41 \%$ (two independent variables) and $69.41 \%$ (two independent variables),

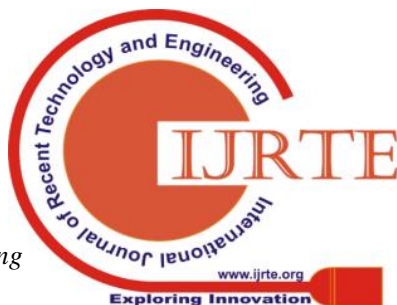


respectively. The discriminated variables treated as essential indicator when selecting the best athletes U21 were shown graphically in Fig. 1. should be equipped with other aspects like motor ability at the best level, power, speed, flexibility and coordination $[17,18]$.

Table 3: Classification matrix by DA for grouping of SUKMA athletes U21

\begin{tabular}{|l|c|c|c|c|c|c|}
\hline \multirow{2}{*}{ Mode of DA } & \multirow{2}{*}{ Sampling group } & \multirow{2}{*}{$\%$ correct } & \multicolumn{2}{|c|}{ Group assigned by DA } & \multirow{2}{*}{ Total } \\
\cline { 4 - 6 } & & & WL & FT & ST & \\
\hline \multirow{2}{*}{$\begin{array}{l}\text { Standard stepwise } \\
\text { (3 independent } \\
\text { variables) }\end{array}$} & WL & $69.23 \%$ & 18 & 7 & 1 & 26 \\
\cline { 2 - 6 } & FT & $72.22 \%$ & 5 & 26 & 5 & 36 \\
\cline { 2 - 6 } $\begin{array}{l}\text { Backward stepwise } \\
\text { (2 independent } \\
\text { variables) }\end{array}$ & ST & $56.52 \%$ & 2 & 8 & 13 & 23 \\
\cline { 2 - 6 } & Total & $\mathbf{6 7 . 0 6 \%}$ & $\mathbf{2 5}$ & $\mathbf{4 1}$ & $\mathbf{1 9}$ & $\mathbf{8 5}$ \\
\cline { 2 - 6 } & WL & $73.08 \%$ & 19 & 7 & 0 & 26 \\
\hline \multirow{2}{*}{$\begin{array}{l}\text { Forward stepwise } \\
\text { (2 independent } \\
\text { variables) }\end{array}$} & FT & $75.00 \%$ & 5 & 27 & 4 & 36 \\
\cline { 2 - 6 } & ST & $56.52 \%$ & 1 & 9 & 13 & 23 \\
\cline { 2 - 6 } & Total & $\mathbf{6 9 . 4 1 \%}$ & $\mathbf{2 5}$ & $\mathbf{4 3}$ & $\mathbf{1 7}$ & $\mathbf{8 5}$ \\
\cline { 2 - 6 } & WL & $73.08 \%$ & 19 & 7 & 0 & 26 \\
\hline
\end{tabular}

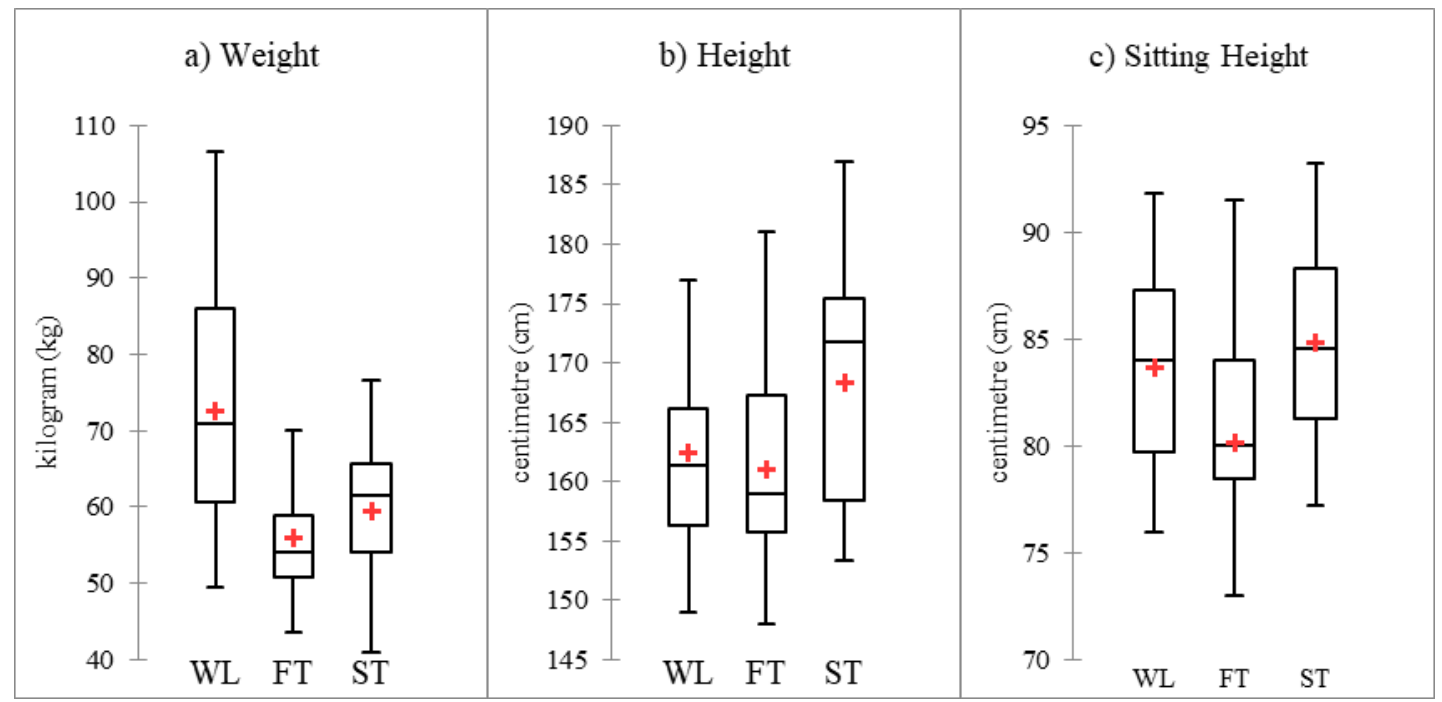

Fig. 1: Box plot of essential indicators for Malaysian body somatotype model.

\section{DISCUSSION}

Descriptive statistics showed the behavior of anthropometric within somatotypes category. It resulting a way of selecting a suitable sport for each athletes according to their somatotypes category. As shown in descriptive statistic, weightlifter comes out with the highest value of mean and standard deviation correlating to weight parameter. It is proven that both correlates well as stated in previous research involved Olympic weightlifters whose competing in body weight levels, it is important for those who compete to keep their body weight maintained [16]. The crucial part is guardedly decreased or increased throughout practice, competition cycles or even training. According to the mean chart of each sports relating to weight parameter, weightlifter proves that it has the highest value where it shows that the athletes are placed accordingly to their somatotypes. However, in order to present the best performance, one
The findings of component DA also exposed three parameters (height, sitting height and weight) correlated well which then brings out a high contribution (85\%) by first factor (F1); as a factor of model to be developed. Based on the analyzed data using Quartile analysis, the researcher managed to construct an athletic body somatotype model, Moreover, most of the futsal athletes are mesomorphic, which is a characteristic that is highly presented as an important factor when recruiting players [19,20,21]. Better teams were associated with much lower body fat percentages compared to the teams with a higher percentage of body fat [22]. As for weightlifter players are dominantly endomorphic. Sepak takraw has a high number of ectomorphic players. The results obtained from the current research imply that weight, height, sitting height and arm span were found significant to use in order to get the 
somatotypes model of athletes for selection in sports. Over all, present finding in line with previous study stated anthropometric contributed high variation regarding the somatotype model of athletes to recognize the best young athletes for particular sports [23,24].

As for height parameter, sepak takraw performed as the dominant group with the highest mean value compared to the other sports. However,

there is no additional information regarding height with performance in sepak takraw and the exact significance of height remains unclear [25].

\section{CONCLUSION}

This study has applied multivariate method known as Discriminant Analysis to model the anthropometric measurements for identifying type of physical body among athletes. DA successfully discriminate three groups of somatotype which are endomorph, mesomorph and ectomorph. It revealed three discriminated variables (weight, height and sitting height) that differentiate all the groups. Such variables were established as compulsory to be taken as they are indicators for identifying body somatotype category among U21 athletes. Current findings also presented that the application of multivariate analysis is required to obtain best result of identifying the somatotype category for athletes. Therefore, this can help researchers, coaches and trainers to save time and cost in the process of development of athlete.

\section{ACKNOWLEDGMENT}

The authors would like to thank Research and Development Management Unit, University of Sultan Zainal Abidin (UniSZA) and Terengganu State Sports Council for their full support in this research.

\section{REFERENCES}

1. B. Knechtle, P. Knechtle, C. A. Rüst, and T. Rosemann, "A comparison of anthropometric and training characteristics of Ironman triathletes and Triple Iron ultra-triathletes," Journal of Sports Sciences, vol. 29, no. 13, pp. 1373-1380, 2011.

2. G. J. Slater, "Physique traits of lightweight rowers and their relationship to pp. 736-741, 2005.

3. C. C. Marta, D. A. Marinho, T. M. Barbosa, A. L. Carneiro, M. Izquierdo, and M. C. Marques, "Effects of Body Fat and Dominant Somatotype on Explosive Strength and Aerobic Capacity Trainability in Prepubescent Children," Journal of Strength and Conditioning Research, vol. 27, no. 12, pp. 3233-3244, 2013.

4. Ö. Orhan, M. Sagir, and E. Zorba, "Comparison of somatotype values of football players in two professional league football teams according to the positions," Collegium antropologicum, vol. 37, vol. 2, pp. 401-405, 2013.

5. "The Heath-Carter Anthropometric Somatotype," Physique, Fitness, and Performance, Second Edition Exercise Physiology, pp. 185-219, 2007.

6. T. J. Gabbett, "Physiological characteristics of junior and senior rugby league players," British Journal of Sports Medicine, vol. 36, no. 5, pp 334-339, 2002.

7. M. R. Abdullah, R. M. Musa, N. A. Kosni, A. B. H. M. Maliki, and M. Haque, "Profiling and Distinction of Specific Skills Related Performance and Fitness Level between Senior and Junior Malaysian Youth Soccer Players," International Journal of Pharmaceutical Research, vol. 8, no. 3, pp. 64-71, 2016.

8. M. S. N. A. Hassan, A. Z. Azhar, N. Kamaruddin, and A. Mohamad, "Perspective of Malaysian Youths towards Homosexuals," Indian Journal of Public Health Research \& Development, vol. 10, no. 4, pp. 747, 2019. competitive success," British Journal of Sports Medicine, vol. 39, no. 10,

9. M. H. Abdullah, H. Juahir, F. Lananan, M. K. A. Kamarudin, A. Ghazali, A. Azemin, N.A. Wahab, S.M. Mat-Rasid, M. H. M. Saad, "Pattern recognition of Melaleuca cajuputi powell essential oils fingerprint in Terengganu, Malaysia using chemometric approach," International Journal of Engineering and Technology (UAE), vol. 7, no. 14, pp. $132-138,2018$.

10. A. Norzaida, S. M. Mat-Rasid, M. D. Zalina, and A. H. Syafrina, "Probability distributions comparative analysis in assessing rainfall process in time and space," International Journal of Civil Engineering and Technology, vol. 8, no. 10, pp. 1679-1688, 2017.

11. M. R. Abdullah, A. B. H. M. Maliki, R. M. Musa, N. A. Kosni, H. Juahir, and M. Haque, "Multi-Hierarchical Pattern Recognition of Athlete's Relative Performance as A Criterion for Predicting Potential Athletes," Journal of Young Pharmacists, vol. 8, no. 4, pp. 463-470, 2016.

12. M. R. Abdullah, R. M. Musa, A. B. H. M. Maliki, N. A. Kosni, and M. A Aziz, "The Application of Principle Components Analysis to Identify Essential Performance Parameters in Outfield Soccer Players," Research Journal of Applied Sciences, vol. 11, pp. 1199-1205, 2016.

13. E. Eyduran, K. Karakus, S. Karakus, and F. Cengiz, "Usage of factor scores for determining relationships among body weight and some body measurements," Bulgarian Journal of Agricultural Science, vol. 15, no. 4, pp. 374-378, 2009.

14. A. B. H. M. Maliki, M. R. Abdullah, H. Juahir, F. Abdullah, N. A. S Abdullah, R. M. Musa, S. M. Mat-Rasid, A. Adnan, N. A. Kosni, W. S. A. W. Muhamad, and N. A. M. Nasir, "A multilateral modelling of Youth Soccer Performance Index (YSPI)," IOP Conference Series: Materials Science and Engineering, vol. 342, pp. 012057, 2018.

15. A. B. H. M. Maliki, M. R. Abdullah, H. Juahir, W. S. A. W. Muhamad, N A. M. Nasir, R. M. Musa, S. M. Mat-Rasid, A. Adnan, N. A. Kosni, F. Abdullah, and N. A. S. Abdullah, "The role of anthropometric, growth and maturity index (AGaMI) influencing youth soccer relative performance," IOP Conference Series: Materials Science and Engineering, vol. 342, pp. 012056, 2018.

16. J. Garhammer, "Performance evaluation of Olympic weightlifters," Medicine \& Science in Sports \& Exercise, vol. 11, no. 3, 1979.

17. N. I. Yusoff, M. R. Abdullah, H. Juahir, J. L. F. Lee, S. M. Mat-Rasid, N. A. Kosni, and M. K. Zawi, "The Effect of Residence Area on Motor Skill Development among Children," Indian Journal of Public Health Research \& Development, vol. 10, no. 3, pp. 614, 2019.

18. M. A. G. @ Charles, M. R. Abdullah, R. M. Musa, N. A. Kosni, and A. B. H. M. Maliki, "The Effectiveness of Traditional Games intervention program in the Improvement of Form One School-Age Children's Motor Skills Related Performance Components," Movement, Health \& Exercise, vol. 6, no. 2, 2017.

19. S. Popovic, S. Akpinar, D. Jaksic, R. Matic, and D. Bjelica, "Comparative Study of Anthropometric Measurement and Body Composition between Elite Soccer and Basketball players," International Journal of Morphology, vol. 31, no. 2, pp. 461-467, 2013.

20. Z. Taha, M. Haque, R. M. Musa, M. R. Abdullah, A. B. H. M. Maliki, N. Alias, and N. A. Kosni, "Intelligent Prediction of Suitable Physical Characteristics Toward Archery Performance Using Multivariate Techniques," 2009.

21. Z. Taha, R. M. Musa, A. P. P. A. Majeed, M. R. Abdullah, M. A. Zakaria, M. M. Alim, J. A. M. Jizat, and M. F. Ibrahim, "The identification of high potential archers based on relative psychological coping skills variables: A Support Vector Machine approach," IOP Conference Series: Materials Science and Engineering, vol. 319, pp. 012027, 2018.

22. A. Arnason, S. B. Sigurdsson, A. Gudmundsson, I. Holme, L. Engebretsen, and R. Bahr, "Physical Fitness, Injuries, and Team Performance in Soccer," Medicine \& Science in Sports \& Exercise, vol. 36, no. 2, pp. 278-285, 2004.

23. M. R. Abdullah, R. M. Musa, A. B. H. M. Maliki, N. A. Kosni, and P. K. Suppiah, "Development of tablet application based notational analysis system and the establishment of its reliability in soccer," Journal of Physical Education and Sport, vol. 16, no. 3, pp. 951, 2016.

24. R. M. Musa, M. R. Abdullah, H. Juahir, V. Eswaramoorthi, N. Alias, M. R Hashim, and A. S. F. Alnamat, "An Exploratory Study of Personality Traits and Psychological Coping Skills on Archery Performance," Indian Journal of Public Health Research \& Development, vol. 10, no. 3, pp. 630, 2019.

25. M. N. Jawis, "Anthropometric and physiological profiles of sepak takraw players Commentary," British Journal of Sports Medicine, vol. 39, no. 11 , pp. 825-829, 2005. 